Celtic: A Journal of Culture, English Language Teaching, Literature and Linguistics

Vol. 7, No. 2, December 2020.

E-ISSN: 2621-9158 P-ISSN:2356-0401

http://ejournal.umm.ac.id/index.php/celtic/index

\title{
INTEGRATION OF "WRITE AND IMPROVE" AWE TOOL INTO EFL AT HIGHER EDUCATIONAL ESTABLISHMENT: CASE STUDY
}

\author{
${ }^{1}$ Kateryna Karpova* \\ ${ }^{1}$ Taras Shevchenko National University of Kyiv, Ukraine \\ *Corresponding Author: karpova_k@ukr.net
}

\begin{abstract}
Dramatic changes in political, economic, cultural, scientific, and technological spheres, which have taken place in recent decades, have caused noticeable alterations in different societal domains, including education. Through the prism of the modern educational paradigm that mainly focuses on meeting the needs of human beings, nowadays, a special place is occupied by ICTs and their integration into the educational process. The present research is devoted to both theoretical evidence and practical implementation of automated writing evaluation (AWE) tool "Write and Improve" into language learning at a higher educational establishment. We use experimental method titled case study, which allows finding out ways to incorporate the software mentioned above into EFL. First and foremost, the author analyses fundamental and contemporary studies in the realm of ICT integration into language teaching, learning, and assessment. Special attention is paid to AWE as cutting-edge software, which utilizes artificial intelligence to assess students' writing. The data under investigation indicate that using AWE computer-assisted programs facilitates students' management and increases motivation for writing and revision. The article sets a goal to demonstrate that "Write and Improve" is an example of innovative technology to enhance writing as an essential academic competency. Based on profound theoretical substantiations, the author conducts the experiment to test the research hypothesis in the case study. Within the framework of the article's written tasks, university students who study English as their major subject at the Taras Shevchenko National University of Kyiv have been chosen. The attempted investigation proved "Write and Improve" to be highly effective among language learners, thus worth being introduced not only into teaching and learning but also assessment.
\end{abstract}

Keywords: AWE (Automated Writing Evaluation); case study; EFL; ICTs (Information and Communication Technologies); "Write and Improve" Tool

\begin{abstract}
ABSTRAK
Perkembangan yang dramatis dalam bidang politik, ekonomi, budaya, ilmiah, dan teknologi yang terjadi dalam beberapa dekade terakhir telah menyebabkan perubahan yang nyata di masyarakat, termasuk dalam bidang pendidikan. Melalui prisma paradigma pendidikan modern yang menitik-beratkan pada pemenuhan kebutuhan manusia, saat ini TIK memiliki tempat khusus dalam hal integrasinya ke dalam proses pendidikan, termasuk dalam proses pembelajaran Bahasa Inggris. Penelitian ini secara spesifik membahas alat Automated Writing Evaluation (AWE) yang bernama "Write and Improve" dalam pembelajaran bahasa di pendidikan tinggi. Pertama, penulis menganalisis berbagai penelitian di bidang integrasi TIK ke dalam pengajaran, pembelajaran, dan penilaian bahasa dengan fokus khusus kepada perangkat AWE sebagai perangkat lunak mutakhir yang memanfaatkan kecerdasan buatan untuk menilai tulisan siswa. Analisa data menunjukkan bahwa penggunaan perangkat AWE mampu memfasilitasi manajemen siswa dan meningkatkan motivasi untuk menulis dan merevisi. Secara lebih spesifik, perangkat lunak "Write and Improve" menjadi contoh teknologi inovatif yang mampu meningkatkan kemampuan menulis sebagai kompetensi akademis yang penting.
\end{abstract}


Karpova, K. (2020). Integration of "Write and Improve" AWE Tool into EFL at Higher

Educational Establishment: Case Study. Celtic: A Journal of Culture, English Language

Teaching, Literature and Linguistics, 7(2), 137-150.

Selanjutnya, penulis melakukan eksperimen untuk menguji hipotesis penelitian dalam studi kasus melibatkan mahasiswa jurusan bahasa Inggris di Universitas Nasional Kyiv Taras Shevchenko. Hasil eksperimen menunjukkan bahwa "Write and Improve" efektif digunakan di antara pelajar bahasa, sehingga layak diperkenalkan tidak hanya ke dalam pengajaran dan pembelajaran tetapi juga penilaian.

Kata Kunci: $A W E$ (Automated Writing Evaluation); Studi Kasus; EFL; TIK; Perangkat "Write and Improve"

\section{INTRODUCTION}

It is widely acknowledged that the past education was predominantly unidirectional, i.e., the information was transferred from the teacher to the student. Subsequently, the main educational approach consisted of classroom teaching and learning that seems obsolete at present, especially in the COVID-19 outbreak condition. Considering global challenges, ground-breaking approaches to teaching and learning should be explored to facilitate students' self-sufficiency and give them access to digital resources more independently than previously. Furthermore, Hubbard (2019) claimed "Technology does not do much by itself that is of value to learning languages. Rather, it serves as a mediator between learners and other actors or language resources, like texts or videos. Educational considerations of our century have led to the surge of new mechanisms and innovations in language teaching and learning, a crucial role in which belongs to information and communication technologies (ICTs)". Unfortunately, ICTs have not yet been fully embedded into education, so their systematic implementation and meticulous analysis are of utmost importance.

It is generally recognized that the use of ICT for educational purposes has greatly revolutionized both teaching and learning. Gudmanian and Sydorenko (2020) mentioned that from the students' perspective, academics could only remain relevant today if they go online. Bilyalova (2017), who studied integration of ICTs into high school level claimed: "At each stage of cognitive activity, research and practical applications in all branches of knowledge ICT perform both the functions of tools and objects of knowledge. Consequently, ICT innovations not only provide a revolutionary development in this branch of knowledge, but also have a direct impact on the scientific and technological progress in all areas of society. Thus, information and communication technologies are a class of innovative technologies for the rapid accumulation of intellectual and economic potential of strategic resources, ensuring sustainable development of society". Studies reveal that ICT usage enhances educational performance and improves students' results in various language competency spheres, including reading, writing, listening, and speaking, respectively.

Hence, several examinations (Bilyalova, 2017; Dudeney \& Hockly, 2007; Ferguson-Patrick et al., 2018; Hubbard, 2019; Samarakoon et al., 2017) have underlined that the positive influence of ICTs in higher education is undeniable since it supports increased students' involvement as well as personalized access to information. The usage of ICTs in acquiring language expertise shifts the focus from the teacher as a source of knowledge to the teacher as a knowledge expert and facilitator of learning, promoting a learner-centered approach as a result. In this regard, a growing number of 
Celtic: A Journal of Culture, English Language Teaching, Literature and Linguistics

Vol. 7, No. 2, December 2020.

E-ISSN: 2621-9158 P-ISSN:2356-0401

http://ejournal.umm.ac.id/index.php/celtic/index

scientific investigations on ICTs have been published in recent decades, which proves vital importance of their further studying.

The theoretical background of implementing state-of-the-art computer-assisted technologies in the educational process has been abundantly available in literature. More precisely, scientific research of ICTs integration in EFL both online and offline covers the following areas: principles of gamification (Bell, 2018; Faiella \& Ricciardi, 2015; Tarnapolsky et al., 2018; Vasileiadou \& Makrina, 2017), using LMS MOODLE as a platform to optimize the process of language acquisition (Trotsko \& Korotkova, 2018; Nahrybelna et al., 2020; Zaiarna, 2020), application of mobile devices to facilitate teaching (Brukhal \& Bilyk, 2017; Soleimani et al., 2016), implementation of blended and/or technology-enhanced language learning (Simpson, 2016; Zhou \& Wei, 2018), stating the opposition between online and offline (face-to-face) EFL (Stickler \& Hampel, 2019), and examination of integrated approaches to teaching (Ferguson-Patrick et al., 2018), etc.

At present considerable attention is given to the crucial importance of enhancing writing as the primary language competency in class or out-of-class, which is highlighted in the theoretical inquiries of such scholars as Manchon (2018), Alharbi (2019), Marques \& Signes (2016). On the level of university education, writing competency deserves a higher priority because advanced writing skills are of primary importance for all students to accomplish their educational requirements (Zadilska, 2017). It is common knowledge that at linguistically-related universities, the skills of writing are developed in both traditional and non-traditional ways, though these days, the preference is given to online tools and platforms which are available either free of charge or pre-paid. In addition, the system of automated writing evaluation ( $A W E$ ) has gathered much attention in recent years (Zhang, 2017; Zhang, 2020). AWE is computer software designed to analyze such features in written texts as the syntax, text complexity, vocabulary choice, grammar, content and development, focus and meaning, style, mechanisms, and convention, depending on the type of AWE itself. After submission of one's written tasks, students are given an overall score, which is frequently supported by suggestions for improvements and corrections, i.e., appropriate feedback. In the sphere of EFL, some attempts have been made to describe either general criteria of AWE implementation (Fang, 2010; Hockly, 2019; Palermo \& Wilson, 2020) or various computer-assisted tools to boost students' writing skills such as Pigai (Bai \& Hu, 2017; Zhang, 2020), Criterion (Li et al., 2015), MYAccess (Grimes \& Warschauer, 2010), WriteToLearn (Liu \& Kunnan, 2016), Grammarly (Dembsey, 2017; Ghufron \& Rosyida, 2018; O’Neill \& Russell, 2019).

Unfortunately, at this point in time, scant attention has been given to the study of AWE software, such as "Write and Improve", which predetermined not only the importance of investigation into the chosen area of EFL studies but also the topicality of the present research. Thus, the purpose of the article is twofold: (1) firstly, it aims at describing "Write and Improve" online AWE tool in the English language learning, teaching and assessment as an effective means to promote students' engagement and writing skills; (2) secondly, it attempts to evaluate the performance of "Write and Improve" in assessing students' written tasks at higher educational establishments and its accuracy in providing appropriate error feedback. 
Karpova, K. (2020). Integration of "Write and Improve" AWE Tool into EFL at Higher Educational Establishment: Case Study. Celtic: A Journal of Culture, English Language Teaching, Literature and Linguistics, 7(2), 137-150.

\section{METHOD}

Firstly, the following scientific methods have been used to make adequate conclusions: (1) critical review of latest publications on the issue of ICTs for educational purposes, namely for EFL; (2) analysis and synthesis: to reveal the effectiveness of AWE Write and Improve; (3) generalization and systematization: to formulate conclusions and determine the directions for further scientific investigation.

Secondly, the experimental part presents the results of the implementation of "Write and Improve" at Taras Shevchenko National University of Kyiv (Kyiv, Ukraine). We had 12 EFL students who study English as the main course of their compulsory educational program English Studies and Two European Languages, at the department of English Philology and Intercultural Communication. There were 10 female and 2 male participants aged 18-20. The data collection took place between January 2020 and June 2020. Intentionally, the $1^{\text {st }}$ year students with different English proficiency levels were selected, ranging from B1 (pre-intermediate) to B2 (upperintermediate). It should be reminded that traditionally students' language proficiency has been assessed using CEFR. It specifies the language proficiency level as follows:

- A1 (beginner)

- A2 (elementary)

- B1 (pre-intermediate)

- B1+ (intermediate)

- B2 (upper-intermediate)

- $\mathrm{C} 1$ (Advanced)

- C2 (Proficient User)

This scheme makes it possible to compare tests and examinations across languages and national boundaries.

This paper's core practical method is a case study, which can be defined as a method of full-scale investigation of a specific case or subject. In addition, Swanborn (2010) researched it as a method of a particular case, which collects information regarding how a certain phenomenon develops within this case during a specific period of time. In particular, this method of scientific analysis is widely employed in sociology and social science (Stake, 1995; Swanborn, 2010), political psychology (Kaarbo \& Beasley, 2002), education (Hamidi \& Chavoshi, 2018), business modeling (Oh \& Shong, 2017), various spheres of medicine (Morgan et al., 2016). Some scholars have addressed the issue of illustrative case study, involving participant observation and data analysis (Vasileiadou \& Makrina, 2017), which is believed to be of particular interest in the article. In addition to this, we use observation and interviewing as research instruments to reveal the students' level of satisfaction and attitude to online teaching and learning in general. The results are presented below. Data analysis has been used to prove the research hypothesis.

An array of aforementioned analysis methods allows for substantiation of scientific research on the issue, practical data collection, and further interpretation. Firstly, students involved in the investigation have been assigned with the written tasks, which were performed via "Write and Improve" online. Secondly, students were given corrective feedback performed with the help of the AWE tool. Finally, the researcher interpreted the findings to draw the appropriate conclusion. For the sake of our case 
Celtic: A Journal of Culture, English Language Teaching, Literature and Linguistics

Vol. 7, No. 2, December 2020.

E-ISSN: 2621-9158 P-ISSN:2356-0401

http://ejournal.umm.ac.id/index.php/celtic/index

study, we used AWE "Write and Improve", which is a free online tool developed by Cambridge Assessment English (URL: https://writeandimprove.com/).

\section{FINDINGS AND DISCUSSION}

\section{Description of "Write and Improve" as a means to promote students' engagement and writing skills}

Recent innovations in the sphere of technology have inevitably led to increased uptake of online software that can automatically analyze and assess students' writing through the automated writing evaluation techniques. As it has already been mentioned, the main focus of our article is AWE "Write and Improve", which is defined as a pioneering online technology developed by the Cambridge Assessment English Project at the University of Cambridge to assess writing skills quickly and give feedback on the students' writing based on the Common European Framework of Reference for Languages: Learning, Teaching, Assessment (CEFR). Within "Write and Improve" software, students are attributed to summative feedback according to the levels of CEFR elaborated above.

As stated before, the study of AWE technologies, namely "Write and Improve" in EFL, is not clear cut, so it needs further scientific examination. To contribute to this investigation and evaluate its effectiveness, we singled out the components of the software, specifically its name, designer, and criteria for corrective feedback. The results are summarized in Table 1.

Table 1. Description of constituent parts of AWE "Write and Improve"

\begin{tabular}{lll}
\hline Name of AWE & Designer of AWE & Criteria for corrective feedback \\
\hline Write and & Cambridge University & Content \\
Improve & Cambridge Assessment of English & $\begin{array}{l}\text { Communicative achievement } \\
\text { Organization } \\
\end{array}$ \\
& & Language \\
\hline
\end{tabular}

Moreover, we presented the screenshot of the AWE "Write and Improve" user interface in Figure 1 below. In the present paper, we focus only on the initial section of the program, namely $W \& I$ Workbooks, for the reason that it is available free of charge. Both participants of the educational process, i.e., teachers and students, can either create their own profile or sign in if they have already created one. Additionally, the interface of "Write and Improve" suggests samples of written tasks for every CEFR level ranging from Beginner (A1) to Advanced (C1). Moreover, additional tasks in sections $W \& I$ Business and $W \& I J u s t$ for fun are available for those who study English for specific or professional purposes and for the sake of entertainment. Besides, the software enables the students to test their writing skills with the Test Zone section (to prepare for international Cambridge exams: IELTS General, IELTS Academic, B2 First training) and Class View section (Additional ready-to-use tasks). 
Karpova, K. (2020). Integration of "Write and Improve" AWE Tool into EFL at Higher Educational Establishment: Case Study. Celtic: A Journal of Culture, English Language Teaching, Literature and Linguistics, 7(2), 137-150.

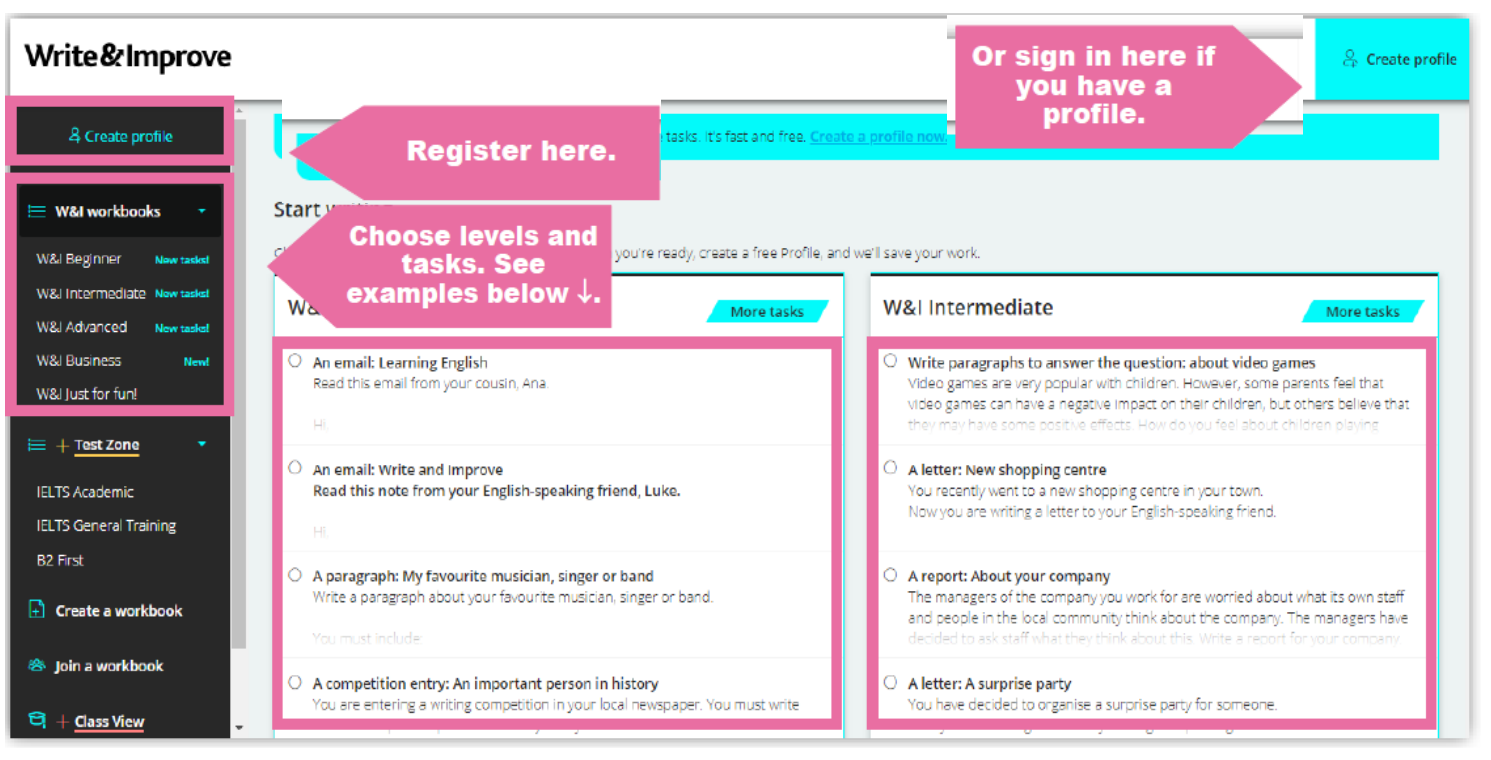

Figure 1. Screenshot of AWE "Write and Improve" user interface

According to Ghufron \& Rosyida (2018), one of the most effective ways to correct students' errors in EFL writing is corrective feedback. In EFL writing, corrective feedback is a traditional strategy implemented by teachers worldwide. Corrective feedback is widely used to educate students' inductively by criticizing and providing comments on their works. One of the types of corrective feedback is indirect corrective feedback, which presupposes that students are given indications with highlighted parts. The indications are given in different ways, such as highlighting, underlining, or coding. After giving indirect feedback, the students will be able to make self-correction or/and self-reformulation.

It must be taken into account that teacher's corrective feedback is usually done manually since teachers give their comments and notes dealing with the students' writing. In our research, we try to identify how computer software such as the AWE tool "Write and Improve" could contribute to English language teaching and learning, especially in terms of writing. The possibilities of corrective feedback provided by the software "Write and Improve" are shown in Table 2.

Table 2. Corrective feedback provided by AWE "Write and Improve"

\begin{tabular}{lll}
\hline $\begin{array}{l}\text { Criteria for assessing written } \\
\text { tasks in terms of corrective } \\
\text { feedback }\end{array}$ & $\begin{array}{l}\text { Sense of the criterion in terms } \\
\text { of affirmation }\end{array}$ & $\begin{array}{l}\text { Sense of the criterion in terms of } \\
\text { interrogation }\end{array}$ \\
\hline Content & $\begin{array}{l}\text { How well the learner has } \\
\text { completed the task }\end{array}$ & $\begin{array}{l}\text { How has the learner completed the } \\
\text { task? }\end{array}$ \\
\hline Communicative achievement & $\begin{array}{l}\text { How appropriate the writing is } \\
\text { for the task }\end{array}$ & Is the task formal/informal? \\
\hline Organization & $\begin{array}{l}\text { How the learner puts together } \\
\text { the piece of writing }\end{array}$ & Is the task in a logical order? \\
\hline Language & Vocabulary and grammar & $\begin{array}{l}\text { Are the language means, } \\
\text { morphology, and syntax accurate? }\end{array}$ \\
\hline
\end{tabular}


Celtic: A Journal of Culture, English Language Teaching, Literature and Linguistics

Vol. 7, No. 2, December 2020.

E-ISSN: 2621-9158 P-ISSN:2356-0401

http://ejournal.umm.ac.id/index.php/celtic/index

As can be seen from Table 2, students' writing competence is assessed, bearing in mind the following criteria of assessment: content, communicative achievement, organization, language. To clarify the meaning of these criteria, we formulated them in terms of affirmation and interrogation.

It is a truism that rapid development of World Wide Web and artificial intelligence has revolutionized the process of teaching and learning English as a foreign language over the past years. Recent years have seen a steady embedding of digital technologies both in class and out of class. As a result, computer-assisted online tools for automated writing evaluation have become increasingly popular to help language learners to acquire and boost their practical skills in writing. In addition to the primary function of tasks assessing and scoring, AWE systems are used to provide automated feedback on errors in students' tasks (error feedback). Moreover, while correcting the students' errors, they offer suggestions on discourse elements such as organization and development of ideas (discourse feedback) (Liu \& Kunnan, 2016). The interactive feedback between various AWE systems and language learners has turned to be a success due to the fact that after submitting their tasks, students can be provided with immediate and helpful feedback, which allows them to focus on different aspects of language expertise (Bai \& Hu, 2017; Liu \& Kunnan, 2016; Palermo \& Wilson, 2020; Zhang, 2020). It must be considered that automated writing evaluation systems are considered to have visible advantages compared with correction and assessment by a human being. Zhang (2020) explains that from the teacher's perspective, perhaps the most outstanding merit of AWE programs is that they liberate teachers from the heavy workload of marking students' essays. As well as having evident advantages in propelling the quality of written tasks, AWE tools possess some drawbacks as well. Li et al. (2015) admit that for lower-proficiency learners, there is evidence that AWE tools' automated features may decrease learning or that requiring individualized feedback is not provided by AWE.

These days various writing techniques in ELT, including process writing, are gaining momentum. In line with Cambridge Assessment Scale, process writing allows both teachers and students to create a text together. In process writing, students have the chance to speculate on what they are going to write, produce drafts, revise, edit, and subsequently receive feedback on their work before coming up with the final version. Process writing employed by "Write and Improve" is an ultimately effective means to ensure we meet Cambridge Criteria for assessing writing (content, communicative achievement, organization, language), mentioned above in Table 2. The mechanism of process writing via "Write and Improve" is illustrated in Figure 2. 
Karpova, K. (2020). Integration of "Write and Improve" AWE Tool into EFL at Higher Educational Establishment: Case Study. Celtic: A Journal of Culture, English Language Teaching, Literature and Linguistics, 7(2), 137-150.

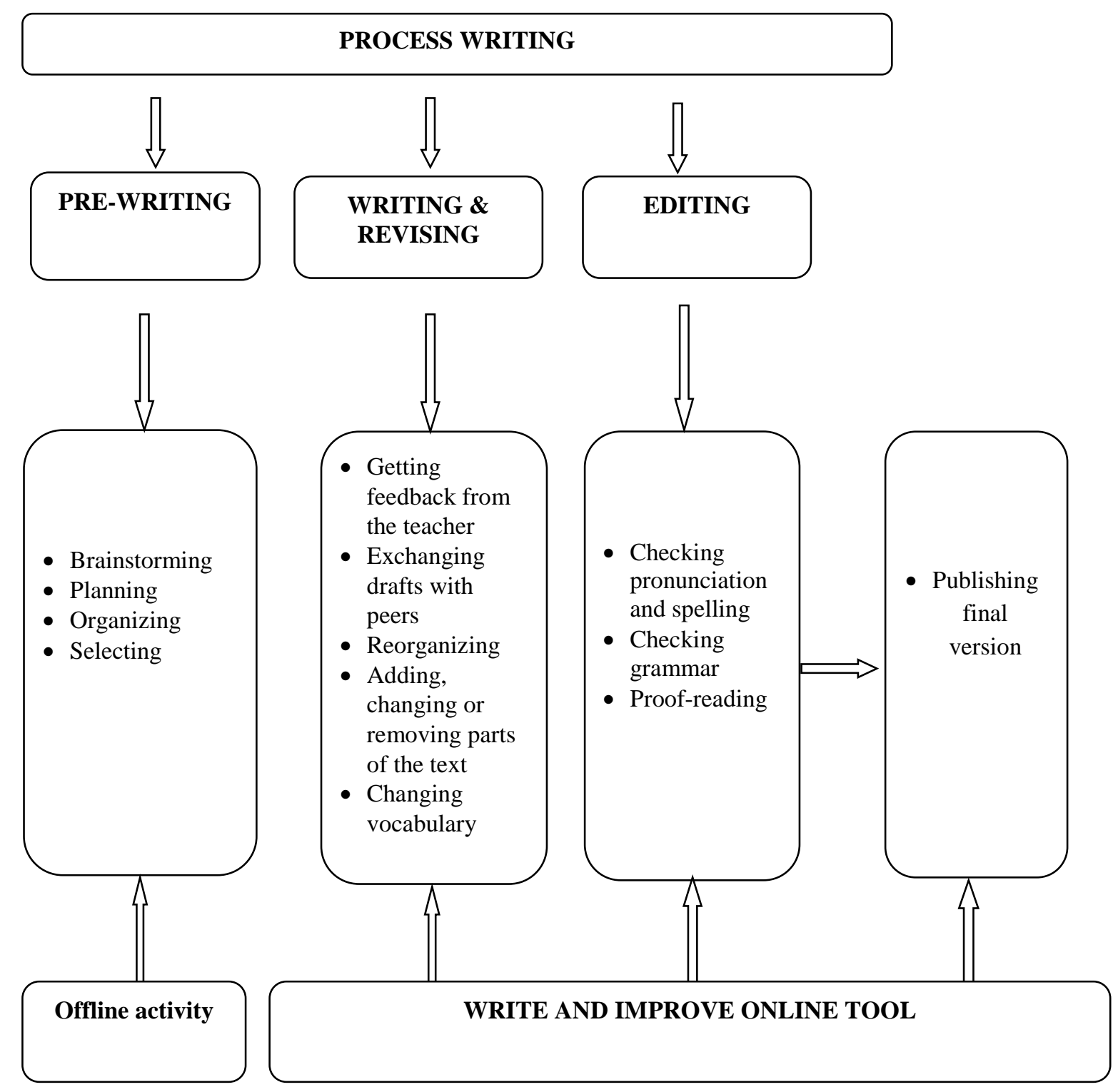

Figure 2. The mechanism of AWE "Write and Improve" following Process Writing

\section{Evaluation of the performance of "Write and Improve" in assessing students' writing}

One of the aforementioned objectives of the present article is to prove the research hypothesis that integration of ICT, namely AWE "Write and Improve" online software, can help students develop and enhance their writing.

To this purpose, the interviewees were asked the following questions:

1. Are you satisfied with online teaching?

2. Are you familiar with online AWE tools?

3. Is the online AWE tool "Write and Improve" effective means of improving writing skills? 
Celtic: A Journal of Culture, English Language Teaching, Literature and Linguistics

Vol. 7, No. 2, December 2020.

E-ISSN: 2621-9158 P-ISSN:2356-0401

http://ejournal.umm.ac.id/index.php/celtic/index

4. Does the AWE tool "Write and Improve" facilitate the process of learning?

5. Is the process of learning with the AWE tool "Write and Improve" more enjoyable than other software?

6. Is "Write and Improve" feedback more efficient compared to teacher corrective feedback?

As part of our experiment, we interviewed first-year students to find out their viewpoint on the issue of online teaching and the role of ICTs in it. Subsequently, we concentrated on the AWE tool "Write and Improve" integration into EFL teaching, learning, and assessment. The interview results, which reveal students' preferences and needs, are depicted in Figure 3.

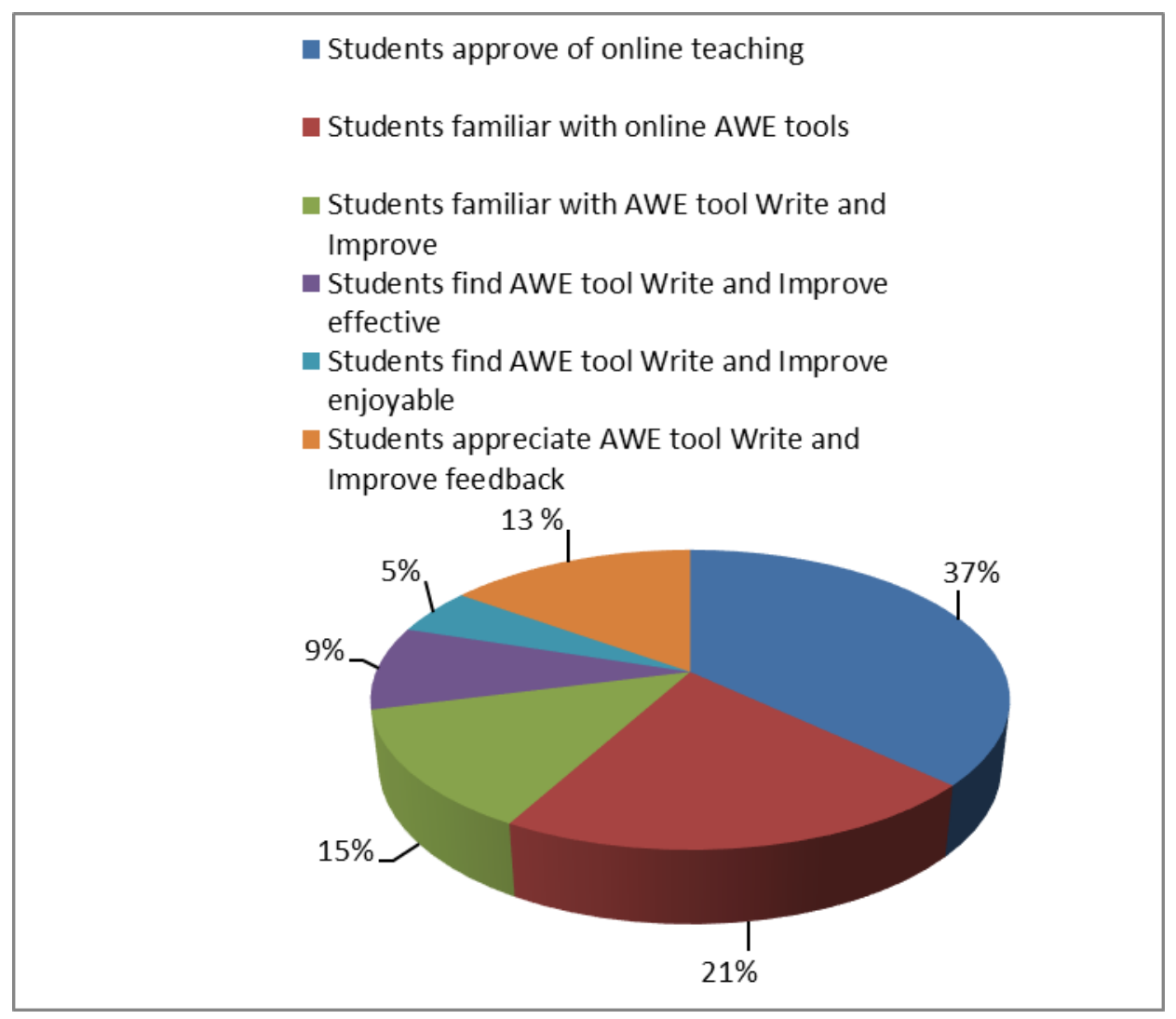

Figure 3. Students' preferences concerning ICTs utilization online, including AWE "Write and Improve"

The pie graph displays the percentage of students who are aware of online learning tools and besides are satisfied with them. After a detailed analysis of interview results depicted by the pie graph, we concluded that the majority of those interviewed (37\%) opt for online rather than offline teaching even in case of its mandatory status for the time being. $9 \%$ and $5 \%$ of students respectively find online AWE tools and enjoyable, making it challenging for EFL. Finally, our findings confirm that systematic embodiment of ICT software in linguistically-related higher educational establishments to boost various communicative competencies proved its efficiency in foreign language 
Karpova, K. (2020). Integration of "Write and Improve" AWE Tool into EFL at Higher Educational Establishment: Case Study. Celtic: A Journal of Culture, English Language Teaching, Literature and Linguistics, 7(2), 137-150.

acquisition. In particular, the online AWE tool "Write and Improve" was regarded by the participants as both an effective and enjoyable way to increase writing skills.

In our research, we implement "Write and Improve" in assessing and correcting students' EFL writing. Consequently, one of the key terms under investigation is assessment. Scholars distinguish between formative and summative types of assessment. Hockly (2019) notes that in a summative of assessment, a major focus of the research has been to what extent AWE programs produce scores for student writing comparable to the scores given by human evaluators a key measure of reliability. The use of AWE for formative assessment to support the development of students' writing seems to be more effective, especially in ELT. The benefits of AWE for both types of assessment are obvious. The automated summative assessment by means of artificial intelligence is extremely fast, therefore it can be primarily significant in the case of large numbers of language learners. When it comes to formative assessment, it may enhance students' motivation. In our research in line with Hockly (2019), we presented both types of assessment in Figure 4.

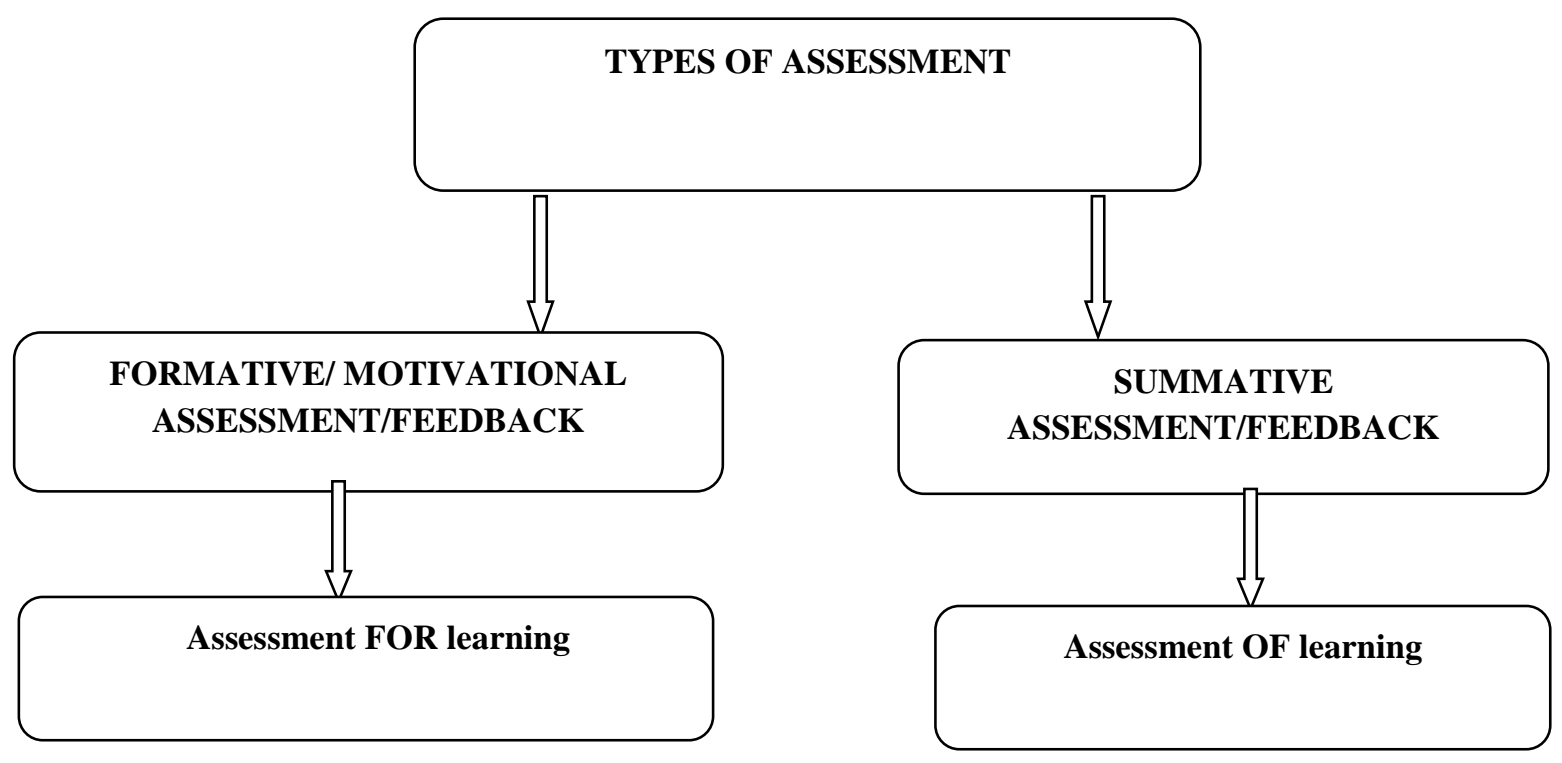

Figure 4. Types of assessment

Bear in mind that AWE "Write and Improve" provides immediate feedback in an interactive format, i.e., students can scroll through their texts, stop at sections that have been highlighted, and read comments provided by the online program. We implement this software to assess and correct students' EFL writing. In this case, the students have been asked to use the software to check their tasks independently. For this purpose, we present an example of the original report on corrective feedback from "Write and Improve" in Figure 5 below: 
Celtic: A Journal of Culture, English Language Teaching, Literature and Linguistics

Vol. 7, No. 2, December 2020.

E-ISSN: 2621-9158 P-ISSN:2356-0401

http://ejournal.umm.ac.id/index.php/celtic/index

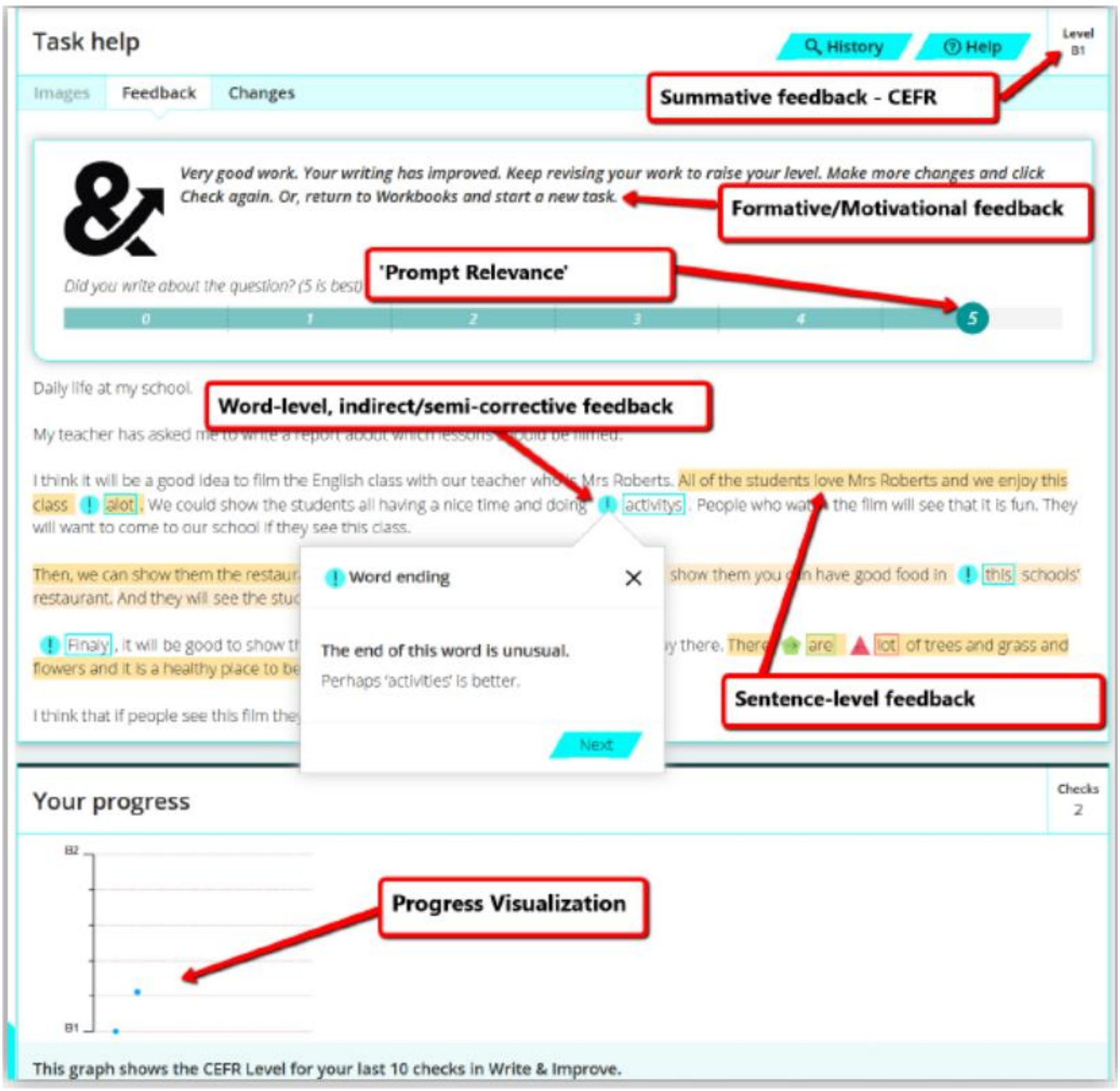

Figure 5. Screenshot of AWE "Write and Improve" corrective feedback

The experiment participants were given the following written task: to write a review on filming the English lesson with their former school teacher. From the perspective of corrective feedback employed, the screenshot presents summative feedback (the student is awarded level B1 according to CEFR), formative feedback (a motivational statement for the student to keep on writing to enhance one's writing skills), and immediate relevance (the student is awarded 5). Moreover, the AWE tool "Write and Improve" gives corrective feedback taking into consideration the following abovementioned criteria: 1. organization (sentence-level feedback); 2. language (wordlevel, indirect/semi-corrective feedback). Finally, it evaluates the level of student's progress from B1 to B2 with the chart "Progress Visualization" below the screenshot. The results reveal its effectiveness when compared to human assessment. 
Karpova, K. (2020). Integration of "Write and Improve" AWE Tool into EFL at Higher Educational Establishment: Case Study. Celtic: A Journal of Culture, English Language Teaching, Literature and Linguistics, 7(2), 137-150.

\section{CONCLUSION}

It is universally known that the world wide web offers a wealth of online resources both for teachers and students, aiming to improve the efficiency of foreign language learning, teaching, and assessment. Hence, the importance of ICT application has been widely discussed and proven in practice. Conducted experiments in the sphere of EFL have shown that the use of various ICTs positively influences the quality of both language teaching and acquisition. Moreover, numerous studies have indicated that the integration of ICT in teaching makes it more dynamic and intense, helps organize the process more effectively, boosts the formation of communicative competencies, provides a positive motivation while learning, and facilitates the independent work of students.

Reviewing theories and practices concludes that the array of online automated writing evaluation (AWE) software effectively enhances the writing competency of students at higher educational establishments. Based on analysis of scientific works on the investigated issue, we came to the following conclusions: (1) implementation of online AWE tools in EFL as an integral part of ICT may be helpful to intensify and individualize learning and assessment; (2) AWE feedback is likely to have a positive influence on increasing EFL writing since it helps to avoid subjective human assessment; (3) the use of "Write and Improve" online in EFL writing proved its efficiency and applicability in terms of organization and language; (4) corrective feedback is a traditional tool employed by "Write and Improve" (set forward by Cambridge Assessment English) for courses on writing to improve students' writing skills.

In the present article, we evaluated the efficiency of "Write and Improve" online tool mainly designed to improve and facilitate students' writing skills at higher educational establishments. Further studies may focus on integrating other online software (e.g. "Speak and Improve" by Cambridge Assessment English) into EFL practice to boost communicative expertise.

\section{Compliance with ethical standards}

Informed consent was obtained from all participants included in the research.

\section{REFERENCES}

Alharbi, M. (2019). Exploring the Potential of Google Doc in Facilitating Innovative Teaching and Learning Practices in an EFL Writing Course. Innovation in Language Learning and Teaching. 14(3), 227-242.

Bai, L. \& Hu, G. (2017). In the Face of Fallible AWE Feedback: How do Students Respond? Educational Psychology. 37(1), 67-81.

Bell, K. (2018). Game on! Gamification, Gameful Design, and the Rise of the Gamer Educator. Johns Hopkins University Press.

Bilyalova, A. (2017). ICT in Teaching a Foreign Language in High School. ProcediaSocial and Behavioral Science. 237, 175-181.

Brukhal, Ya. \& Bilyk, O. (2017). The Essential Features of Technology of Mobile Training Foreign Language as a Pedagogical Innovation. Young scientist. 6(46), 201-205. 
Celtic: A Journal of Culture, English Language Teaching, Literature and Linguistics

Vol. 7, No. 2, December 2020.

E-ISSN: 2621-9158 P-ISSN:2356-0401

http://ejournal.umm.ac.id/index.php/celtic/index

Dembsey, J. (2017). Closing the Grammarly Gaps: a Study of Claims and Feedback from an Online Grammar Program. The Writing Center Journal. 36(1), 63-96.

Dudeney, G. \& Hockly, N. (2007). How to Teach English with Technology. Longman Pearson Education.

Faiella, F. \& Ricciardi, M. (2015). Gamification and Learning: A Review of Issues and Research. Journal of E-learning and Knowledge Society. 11(3), 1-12.

Fang, Y. (2010). Perceptions of the Computer-assisted Writing Program among EFL College Learners. Educational Technology \& Society. 13(3), 246-256.

Ferguson-Patrick, K., Reynolds, R. \& Macqueen, S. (2018). Integrating Curriculum: a Case Study of Teaching a Global Education. European Journal of Teacher Education. 41(2), 187-201.

Ghufron, M. \& Rosyida, F. (2018). The Role of Grammarly in Assessing English as a Foreign Language (EFL) Writing. Lingua Cultura. 12(4), 395-403.

Grimes, D. \& Warschauer, M. (2010). Utility in a Fallible Tool: a Multi-site Case Study of Automated Writing Evaluation. The Journal of Technology, Learning, and Assessment. 8(6), 4-43.

Gudmanian, A. \& Sydorenko, S. (2020). A Web Resource Map for a University Course in the History of the English Language. Information Technologies and Learning Tools. 76(2), 126-136.

Hamidi, H. \& Chavoshi, A. (2018). Analysis of the Essential Factors for the Adoption of Mobile Learning in Higher Education: a Case Study of Students of the University of Technology. Telematics and Infomatics. 35(4), 1053-1070.

Hockly, N. (2019). Automated Writing Evaluation. ELT Journal. 73(1), 82-88.

Hubbard, P. (2019). Five Keys from the Past to the Future of CALL. International Journal of Computer-assisted Language Learning and Teaching. 9(3), 1-13.

Kaarbo, J. \& Beasley, R. (2002). A Practical Guide to the Comparative Case Study Method in Political Psychology. Political psychology. 20(2), 369-391.

Li, J., Link, S. \& Hegelheimer, V. (2015). Rethinking the Role of Automated Writing Evaluation (AWE) Feedback in ESL Writing Instruction. Journal of Second Language Writing. 27, 1-18.

Liu, S. \& Kunnan, A. (2016). Investigating the Application of Automated Writing Evaluation to Chinese Undergraduate English Learners: a Case Study of WriteToLearn. CALICO Journal. 33(1), 71-91.

Manchon, R. (2018). Past and Future Research Agendas on Writing Strategies: Conceptualization, Inquiry Methods, and Research Findings. Studies in Second Language Learning and Teaching. 8(2), 247-267.

Marques, M. \& Signes, C. (2018). Learning from Learners: a Non-standard Direct Approach to the Teaching of Writing Skills in EFL in a University Context. Innovation in Language Learning and Teaching. 12(2), 164-176.

Morgan, S., Pullon, S., Macdonald, L., McKinlay, E. \& Gray, B. (2016). Case Study Observational Research: a Framework for Conducting Case Study Research where Observation Data are the Focus. Qualitative Health Research. 27(7), 1060-1068.

Nahrybelna, I., Syheiko, L. \& Melnychuk, Yu. (2020). The Implementation of the Distance Course on Teaching the Ukrainian Language by Means of LMS MOODLE. Information Technologies and Learning Tools. 77(3), 162-174. 
Karpova, K. (2020). Integration of "Write and Improve" AWE Tool into EFL at Higher Educational Establishment: Case Study. Celtic: A Journal of Culture, English Language Teaching, Literature and Linguistics, 7(2), 137-150.

Oh, J. \& Shong, I. (2017). A Case Study on Business Model Innovations Using Blockchain: Focusing on Financial Institutions. Asia Pacific Journal of Innovation and Entrepreneurship. 11(3), 335-344.

O’Neill, R. \& Russell, A. (2019). Stop! Grammar Time: University Students' Perceptions of the Automated Feedback Program Grammarly. Australian Journal of Educational Technology. 35(1), 42-56.

Palermo, C. \& Wilson, J. (2020). Implementing Automated Writing Evaluation in Different Instructional Contexts: a Mixed-methods Study. Journal of Writing Research. 12(1), 63-108.

Samarakoon, S., Christiansen, A. \& Munro, P. (2017). Equitable and Quality Education for All of Africa? The Challenges of Using ICT in Education. Perspectives on Global Development and Technology. 16(6), 645-665.

Simpson, A. (2016). The Successful Incorporation of Blended Learning into the Language Curriculum. Advanced Education. 5, 96-107.

Stake, R. (1995). The Art of Case Study Research. Sage Publications.

Stickler, U. \& Hampel, R. (2019). Qualitative Research in Online Language Learning: What can it do? International Journal of Computer-assisted Language Learning and Teaching. 9(3), 14-28.

Soleimani, H., Saeedi, A. \& Rahmanian, M. (2016). Security Challenges in Mobile Assisted Language Learning in Millennium for Education. Advanced Education. 6, 4-10.

Swanborn, P. (2010). Case Study Research: What, Why and How. India: Sage.

Tarnapolsky, O., Kozhushko, S. \& Kabanova, M. (2018). Gamification in Foreign Language Teaching at Higher Schools. Foreign Languages. 3(95), 15-22.

Trotsko, A. \& Korotkova, U. (2018). Using Information and Communication Technologies in the Process of Teaching Foreign Languages: The Experience of Ukraine and Greece. Information Technologies and Learning Tools. 68(6), 166180.

Vasileiadou, I. \& Makrina, Z. (2017). Using Online Computer Games in the ELT Classroom: a Case Study. EFL Journal. 10(12), 134-150.

Zadilska, H. (2017). The Modern Technologies of Forming of Competence of English Writing of Students of the Linguistic Departments. Molod' i Rynok. 147(4), 4246.

Zaiarna, I. (2020). The Model for E-teaching English Reasoning Writing to Law Students based on LMS Moodle. Information Technologies and Learning Tools. 76(2), 152-162.

Zhang, Z. (2017). Student Engagement with Computer-generated Feedback: Case Study. EFL Journal. 71(3), 317-328.

Zhang, Z. (2020). Engaging with Automated Writing Evaluation (AWE) Feedback on L2 Writing: Student Perceptions and Revisions. Assessing Writing. 43, 2-14.

Zhou, Ya. \& Wei, M. (2018). Strategies in Technology-enhanced Language Learning. Studies in Second Language Learning and Teaching. 8(2), 471-495. 